
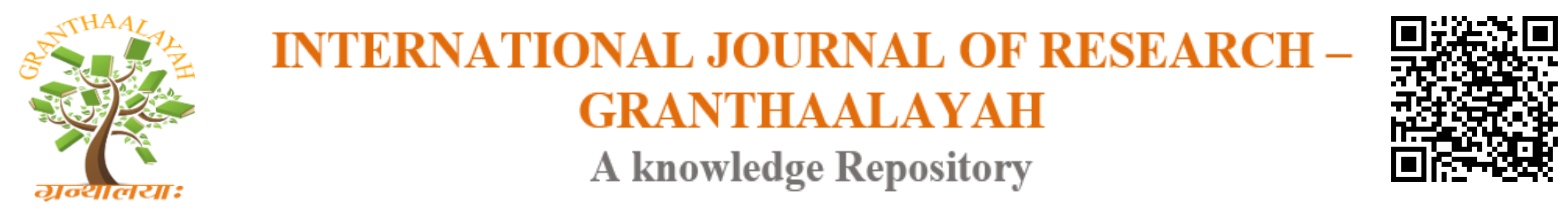

Management

\title{
FACTORS AFFECTING THE PERCEPTION OF INVESTORS TOWARDS EQUITY AND DERIVATIVES IN INDORE CITY
}

\author{
Ms. Disha Gupta ${ }^{1}$, Dr. Priyanka Mokshmar ${ }^{2}$ \\ ${ }^{1}$ Research Scholar, Institute of Management Studies, DAVV, Indore, India \\ ${ }^{2}$ Research Guide, DAVV, Indore, India
}

\begin{abstract}
Investment is referred as an activity on commitment on the funds available at present in any nonfinancial and financial instruments so as to receive the profitable return in the future. An investment is always done with particular objectives. As a matter of fact in investor who does not possess investment knowledge is only subconsciously allowed about the investment objective. This implies that there are a number of factors that affect the perception of investors towards investment. The perception of investor with respect to the decision about investment avenues is different in is dependent upon major demographic factors like income, age, social needs and experience. This paper aims to analyse the factors that affect the perception of investors towards equity and derivatives in Indore city. The study employs primary data in a number of factors affecting the perception of investors towards equity and derivatives are revealed.
\end{abstract}

Keywords: Equity; Derivatives; Investment; Risk and Return.

Cite This Article: Ms. Disha Gupta, and Dr. Priyanka Mokshmar. (2018). "FACTORS AFFECTING THE PERCEPTION OF INVESTORS TOWARDS EQUITY AND DERIVATIVES IN INDORE CITY.” International Journal of Research - Granthaalayah, 6(2), 274-282. https://doi.org/10.5281/zenodo.1194707.

\section{Introduction}

A well organised financial system results into better economic development of a nation. The Financial Institutions and financial market are part of a financial system in due to that financial system is a very broad term (Acharya \& Richardson, 2009). The responsibility of a financial system is to mobilize the savings in the form of monetary assets and money and then invest it to the productive Ventures. It also tends to promote this Savings and investments that for the results into faster economic development in a nation.

\subsection{Meaning of Investments}

Investment refers to the sacrifice of a specific present value for an uncertain future return. Investments are always challenging and rewarding (Zhang, 2012). As a general 
perception, high risk yields high returns. This further implies that risk and rewards go hand in hand.

If the needs of the investors are satisfied then the investment is considered to be perfect. This makes it very important for an investor to identify the needs to make the investment perfect. This is the major reason why most of the advisors and investors spend a lot of time in understanding the significance and advantages of the investment avenues available in India (Allayannis \& Weston, 2001). In contrast to that, a little time is spent on understanding the needs of the investors and ascertaining the most useful Investment Avenue for them.

In India there are a number of investment avenues available in front of the investors. These avenues are equity shares, non-marketable financial assets, money market instruments, bonds, Life Insurance, mutual funds, precious things, real estate and financial derivatives(Vashishtha \& Kumar, 2010).

\subsection{Investment Avenues}

Derivatives are the instruments that derive their value from other underlying assets. This is why derivatives are viewed as side bet on the assets. Options and futures are most important financial derivatives from the point of view of the investors (Aren \& Aydemir, 2015). But overall it is asserted that derivatives are not very popular mode of investment. Equity refers to the shares of company and they are traded in secondary market. The investors get benefit by the changes in price of the shares and the dividend given by the companies. The equity share also represents ownership capital.

A number of research studies in the past have examined the factors that affect the perception of investors regarding various investment avenues. But there is no study that specifically studied the equity and derivatives market in Indore city. The present research study would conduct primary analysis on the investor's perception regarding equity and derivatives in Indore city.

\subsection{Research Objectives}

Following are the objective of the present research study:

- To understand the perception of investors on equity and derivatives.

- To determine the factors that affects the perception of investors.

- To analyse the investment pattern of investors in the Indore city.

\subsection{Research problem}

Investment is considered to be an integral part of financial system. A nation cannot achieve economic development without Investments. Likewise, the economic development of a city is also based on the investment pattern of the individuals residing in the City. There are many developed cities in India where investment pattern is not certain. Indore is also considered as a developed city in India. But the investment pattern and perception of investors for this city are not known. This makes it very important to undertake a research on the perception of investors 
on equity and derivatives to identify the factors that affect their perception and analyse the investment patterns of the investors in the Indore city.

\section{Material and Method}

It is analysed that when funds are committed with an expectation of positive return in future, then it is referred as an investment. Investments are made with an objective of getting good return (Bandivadekar \& Ghosh, 2003). The most significant aspect upon which the investors are dependent is higher reward. This is the major reason why investors carefully evaluate, plan in allocate funds in a number of investible avenues. The objective of every investor is to get safety of principal and regular return. It is identified that investments made in equity shares are one of the avenues that offer high benefit on higher risk (Sathya, 2015).

The factors that affect the behaviour of investors in capital market have also been analysed. It is identified by the demographic factors like age, gender; income, etc. negatively affect the investment decisions of the investors (Booth, 1999). The perception of investors with respect to regulatory, political, social, technological, economical, legal and environmental risks With respect to the value of equity shares in the market was analysed. It was further identified that regulatory, political, social, technological, economical, legal and environmental factors influence the perception of customer regarding equity share (Chawla, 2014). It was also identified that except for social factor between unmarried investors, regulatory, political and legal factors for occupation in age were insignificant (Saravana, 2010).

The characteristics of investor with respect to strategies, investments and expectations were also examined. This study was based on the information collected from almost 900 individuals from 11 cities of India. The study identified that the increased popularity of equity as an option of investment among the investors is the major finding (Gulen \& Mayhew, 2000).

It is identified in a research study that the most significant factor that affects the investor's decision is risk factor. The investors do not want to take much risk at the time of investment. In addition to that it is also a factor that also prevents a number of investor from making investment decisions (Sarangdevot \& Rathore, 2014). But the research studies also claim that the investment avenues that are more risky tend to provide more returns to the investors. This also acts as a motivation for some investors to take more risk so that they can earn more. Risk is an integral part of the investment and return (Nelson, Moffitt, \& Graves, 2005).

Another significant factor associated with investment is return. It is identified that return is dependent upon the risk taken by the investors. As stated in other researchers that the return would be higher if the risk would be higher (Kathuria \& Singhania, 2010). This makes it very important for the investors to take high risk if they are willing to get high return.

A research study also identified that investors also bother brokerage fees (Sahadevan, 2002). In a research study it is found out that if the broker its fees is high then the investors are less likely to invest in that. This makes it very important for the brokers to keep the brokerage fees low (Nath, 2003). It is also identified that the investors prefer the investment avenues that have low 
brokerage fees then the ones that have high brokerage fees. In case the brokerage fee is high then the investors look for payment solutions as well (Kumar \& Pandey, 2009).

It is further identified in a research study that the government and the regulatory bodies also play a very important role in controlling the decisions related to the investment avenues (Sah \& Omkarnath, 2005). The control by the regulatory bodies make the investors feel secured. It is also identified that the investors prefer to invest in the avenues that are protected by the regulatory bodies. This is something that enables the investor to feel protected and safe (Reddy \& Sebastin, 2008).

\subsection{Research Methodology}

\subsubsection{Sources of Data}

The present research study is based on primary data. To collect the primary data the researcher has used a structured questionnaire. The questionnaire was sent to the respondents using email. To select the respondents the researcher used simple random technique. Total 300 respondents were contacted to collect the data. Thus the sample size for the present research study is 300 .

\subsubsection{Data Analysis Tool}

The present research study aims at analysing the factors that affect the perceptions of the investor with respect to equity and derivatives in Indore city. The most significant tool for the present research study would be factor analysis. This tool would help in factor reduction and getting specific factors for the study.

\section{Results and Discussion}

Before proceeding with data analysis, the researcher employed reliability test. To check the reliability, Chronbach's Alpha was used. Factor analysis is employed to analyse the primary data collected from the study. It has been identified from the analysis that there are five major factors that affect the perception of the investors on equity and derivatives.

Table 1.1: Case processing summary

\begin{tabular}{|c|c|c|c|}
\hline \multicolumn{4}{|c|}{ Case Processing Summary } \\
\hline & & $\mathbf{N}$ & $\%$ \\
\hline \multirow{3}{*}{ Cases } & Valid & 300 & 100.0 \\
\hline & Excluded $^{\mathrm{a}}$ & 0 & .0 \\
\hline & Total & 300 & 100.0 \\
\hline
\end{tabular}

a. Listwise deletion based on all variables in the procedure.

Table 1.2: Reliability statistics

\begin{tabular}{|l|l|}
\hline \multicolumn{2}{|c|}{ Reliability Statistics } \\
\hline Cronbach's Alpha & N of Items \\
\hline .857 & 14 \\
\hline
\end{tabular}


It is identified from the reliability statistics that the value of Alpha is .857 . This suggests that the value is very good and the research can be taken further. The value falling in the levels .70 to .90 is considered to be excellent for replicating the study in future.

The total variance explained denotes the five factors that emerged out of the study. The summary of the five emerged factors is present in the table 1.3.

Table 1.3: Total variance explained

\begin{tabular}{|c|c|c|c|c|c|c|c|c|c|}
\hline \multicolumn{10}{|c|}{ Total Variance Explained } \\
\hline \multirow[t]{2}{*}{ Component } & \multicolumn{3}{|c|}{ Initial Eigenvalues } & \multicolumn{3}{|c|}{$\begin{array}{l}\text { Extraction Sums of } \\
\text { Squared Loadings }\end{array}$} & \multicolumn{3}{|c|}{\begin{tabular}{|c} 
Rotation Sums of Squared \\
Loadings
\end{tabular}} \\
\hline & Total & $\begin{array}{c}\% \text { of } \\
\text { Variance }\end{array}$ & $\underset{\%}{\text { Cumulative }}$ & Total & $\begin{array}{c}\% \text { of } \\
\text { Variance }\end{array}$ & $\begin{array}{c}\text { Cumulative } \\
\%\end{array}$ & Total & \begin{tabular}{|c|}
$\%$ of \\
Variance
\end{tabular} & $\underset{\%}{\text { Cumulative }}$ \\
\hline 1 & 5.070 & 36.212 & 36.212 & $5.070^{3}$ & 36.212 & 36.212 & 3.487 & 24.908 & 24.908 \\
\hline 2 & 2.287 & 16.333 & 52.546 & 2.287 & 16.333 & 52.546 & 2.070 & 14.789 & 39.697 \\
\hline 3 & 1.765 & 12.610 & 65.156 & 1.765 & 12.610 & 65.156 & 2.042 & 14.583 & 54.280 \\
\hline 4 & 1.301 & 9.294 & 74.450 & 1.301 & 9.294 & 74.450 & 1.998 & 14.268 & 68.548 \\
\hline 5 & 1.004 & 7.172 & 81.623 & 1.004 & 7.172 & 81.623 & 1.830 & 13.075 & 81.623 \\
\hline 6 & .958 & 6.841 & 88.464 & & & & & & \\
\hline 7 & .607 & 4.336 & 92.799 & & & & & & \\
\hline 8 & .295 & 2.104 & 94.904 & & & & & & \\
\hline 9 & .221 & 1.577 & 96.481 & & & & & & \\
\hline 10 & .186 & 1.332 & 97.812 & & & & & & \\
\hline 11 & .149 & 1.062 & 98.874 & & & & & & \\
\hline 12 & .116 & .832 & 99.706 & & & & & & \\
\hline 13 & .041 & .294 & 100.000 & & & & & & \\
\hline 14 & $\begin{array}{l}6.906 \mathrm{E}- \\
017\end{array}$ & $\begin{array}{l}4.933 \mathrm{E}- \\
016\end{array}$ & 100.000 & & & & & & \\
\hline
\end{tabular}

The components matrix table 1.4 denotes the five factors iterated from the study. The table comprises of 14 variables of the study and the five factors that are identified. The five factors are highlighted in the table.

Table 1.4: Component matrix

\begin{tabular}{|l|l|l|l|l|l|}
\hline \multicolumn{5}{|c|}{ Rotated Component Matrix } \\
\hline & \multicolumn{5}{|c|}{ Component } \\
\cline { 2 - 6 } & $\mathbf{1}$ & $\mathbf{2}$ & $\mathbf{3}$ & $\mathbf{4}$ & $\mathbf{5}$ \\
\hline VAR00001 & .863 & .124 & .023 & .087 & -.033 \\
\hline VAR00002 & .630 & .324 & .267 & .442 & .072 \\
\hline VAR00003 & .299 & -.081 & .004 & .856 & .100 \\
\hline VAR00004 & .078 & .209 & -.007 & .053 & .911 \\
\hline VAR00005 & .080 & .929 & .104 & -.061 & .159 \\
\hline VAR00006 & .202 & 122 & .897 & .007 & -.001 \\
\hline VAR00007 & .763 & -.135 & .344 & .223 & .188 \\
\hline
\end{tabular}




\begin{tabular}{|l|c|c|c|c|c|}
\hline VAR00008 & .803 & .095 & -.057 & .027 & -.030 \\
\hline VAR00009 & .630 & .324 & .267 & .442 & .072 \\
\hline VAR00010 & .094 & -.105 & -.004 & .864 & .060 \\
\hline VAR00011 & .052 & .114 & .013 & .109 & .920 \\
\hline VAR00012 & .073 & .919 & .057 & -.087 & .168 \\
\hline VAR00013 & .107 & .062 & .917 & .020 & -.008 \\
\hline VAR00014 & .742 & -.131 & .341 & .209 & .199 \\
\hline
\end{tabular}

Extraction Method: Principal Component Analysis.

Rotation Method: Varimax with Kaiser Normalization.

a. Rotation converged in 6 iterations.

The component matrix denotes that the five variables that are variable 1 , variable 5 , variable 13 , variable 10 and variable 11 have the highest loadings. These are the factors that are the most significant for the study. Of all the five variables the highest loading is for variable 5. The summary of these five variables is presented in the table given below along with their series and loadings:

Table 1.5: Summary of the factors identified

\begin{tabular}{|l|l|l|l|}
\hline Variables & Question & Loading & Factor name \\
\hline Variable 05 & It is less speculative than equity market & 0.929 & Speculation \\
\hline Variable 11 & Brokerage fees is high (equity) & 0.920 & Brokerage \\
\hline Variable 13 & $\begin{array}{l}\text { Investors protection measures are sufficient } \\
\text { (derivatives) }\end{array}$ & 0.917 & Protection \\
\hline Variable 10 & It is safe and less riskier (equity) & 0.864 & $\begin{array}{l}\text { Safety and } \\
\text { risk }\end{array}$ \\
\hline Variable 01 & Derivatives are complex and new financial products & 0.863 & Complexity \\
\hline
\end{tabular}

\subsection{Discussion}

The result of the analysis revolves around the five factors that are speculation, brokerage, protection, safety and risk and complexity. Out of the five factors two factors are related with equity market and rest of the three factors are related to derivatives. It is identified from the analysis that derivatives are considered to be less speculative than equity market by the respondents. This factor has received the highest loading. The second factor is brokerage and it is identified that the brokerage fees is high for equity. The third factor is Investors Protection measures are sufficient in derivatives in this is a positive outcome of the study. The fourth factor emerged out of the study is that equity is safe and less risky. As a matter of fact the factor one and factor four of the study contradicts with each other. It is identified that derivatives are considered less speculative than equity market but equity is considered less risky and safer option. This further reveals that the investors are still confused about their perception with respect to equity and derivatives in the investment market. Another major finding of the study is that derivatives are considered to be Complex and new financial products by the investors. Even after almost one and half decade the derivatives are considered new financial products and are also considered to be complex. This further means that derivatives are still unpopular among the investors. 
The present study aimed at understanding the perception of investors on equity and derivatives. It is identified that the perception of investors towards derivative is still complex. Investors still think that derivatives are innovative financial products. In addition to that the perception of investors towards equity is that the investors are confused about it due to the contradiction in the opinion about two factors. But equity is considered to be less risky and safe by the investors. The research also aimed at determining the factors that affects the perception of investors. It was identified that the factors that affect the perception of the investors are speculation, brokerage, protection, safety and risk and complexity. Along with that there is such also aimed at analysing the investment pattern of investors in the Indore city. The result from factor analysis clearly suggests that equity is preferred by the investors than derivatives.

The findings from the present research study also conform to the implications in the literature. It is identified in a research study that the most significant factor that affects the investor's decision is risk factor. The investors do not want to take much risk at the time of investment. In addition to that it is also a factor that also prevents a number of investor from making investment decisions (Sarangdevot \& Rathore, 2014). The present research study has also identified risk as a very important factor in investment decision making. A research study also identified that investors also bother brokerage fees (Sahadevan, 2002). In a research study it is found out that if the broker its fees is high then the investors are less likely to invest in that. This makes it very important for the brokers to keep the brokerage fees low (Nath, 2003). This also matches with the result of the present research study. The preset research study also identified brokerage as one of the most significant factors.

\section{Conclusion and Recommendations}

The research study sums up in five major factors that are speculation, brokerage, protection, safety and risk and complexity. With these five factors, the research study has achieved the objective as well. It is identified that the investors in Indore city prefer equity over derivatives when it comes to investment pattern. It is also identified that the investors in Indore city are still confused about their perception with respect to equity and derivatives. It is asserted from the fact that the two factors emerged out of the study contradict each other. The finding of the study revealed that the derivatives are considered to be less speculative than equity by the investor on one hand. But the investors perceive equity as safe and less risky on another hand. This clearly suggests that the investors in Indore city are still confused about the preference over equity and derivatives. Along with that it is also identified that the derivatives are considered to be Complex in they are still considered as new instrument of investment.

The implication of present research study is that the investors are still unclear about derivatives. The perception about equity is clear but perception on derivatives is not very clear. The investors in Indore city are also concerned about the brokerage fees. It is identified that the investors are of the opinion that the brokerage fees for equity is high. When trains identified with respect to the investment measured in Indore city. 


\subsection{Recommendations}

On the basis of the findings of the present research studies following recommendations are provided to the investors, brokers and regulatory bodies:

- It is important for the investors in Indore city to think beyond the traditional avenues of the investment. The investors are still not sure about the derivative and their contradictory answers proved so. The investors in Indore city shall also considered derivatives as an option for investment.

- The brokers shall take a note that the brokerage fees shall be kept low. The investor has suggested that brokerage fees for equity are high. This might also affect the investment capacity of the investor and they might not invest.

- The regulatory bodies will have to start campaign to educate people about investment. There is lack of awareness among the investors in Indore city.

\section{References}

[1] Acharya, V., \& Richardson, M. (2009). Derivatives: The Ultimate Financial Innovation. NewYork.

[2] Allayannis, G., \& Weston, J. (2001). The use of foreign currency derivatives and form market value. The review of financial studies.

[3] Aren, S., \& Aydemir, S. D. (2015). The Moderation of Financial Literacy on the Relationship between Individual Factors and Risky Investment Intention. International Business Research, 8 (6), 17.

[4] Bandivadekar, S., \& Ghosh, S. (2003). Derivatives and Volatility on Indian Stock Markets. RBI Occasional Papers, 24 (3), 12-28.

[5] Booth, G. (1999). Price Discovery in the German Equity Index Derivative markets. The Journal of Futures Market, 19 (6), 619-64.

[6] Chawla, D. (2014). An Empirical Analysis of Factors Influencing Investment in Mutual Funds in India. Global Business Review, 15 (3), 493-503.

[7] Gulen, H., \& Mayhew, S. (2000). Stock Index Futures Trading and Volatility in International Equity Markets. The Journal of Futures Markets, 20 (7), 661-685.

[8] Kathuria, L., \& Singhania, K. (2010). Investor Knowledge and Investment Practices of Private Sector Bank Employees. The Indian Journal of Commerce, 63 (3), 79.

[9] Kumar, B., \& Pandey, A. (2009). Role of Indian Commodity Derivatives Market in Hedging Price Risk: Estimation of Constant and Dynamic Hedge Ratio and Hedging Effectiveness. 22 Asralian Finance and Banking Conference 2009.

[10] Nath, G. C. (2003). Behaviour of stock market volatility after derivatives. NSE Working Paper.

[11] Nelson, J., Moffitt, J., \& Graves, J. (2005). The impact of hedging on the market value of equity. Journal of Corporate Finance.

[12] Reddy, Y. V., \& Sebastin, A. (2008). Interaction between Equity and Derivatives Markets in India: An Entropy Approach. ICFAI Journal of Derivatives markets, 5 (1), 18-32.

[13] Sah, A. N., \& Omkarnath, G. (2005). Causal Relationship between Futures Contracts and Volatility of the Spot Market: A Case of S\&P CNX Nifty and Nifty Futures. ICFAI Journal of Derivatives Markets, 2 (2), 64-71.

[14] Sahadevan, K. G. (2002). Derivatives and Risk Management: A Study of Agricultural Commodity Futures in India. Research Project Report, Indian Institute of Management, Lucknow.

[15] Sarangdevot, S., \& Rathore, Y. (2014). Growth \& Future of Derivatives in India: A Study. Int'l Journal of Computing, Communications \& Instrumentation Engg. (IJCCIE). 
[16] Saravana, S. (2010). An Analysis of Investor Preference towards Equity and Derivatives. The Indian Journal of Commerce, 63 (3), 71.

[17] Sathya, S. (2015). A Comparative Study on Equity, Commodity, Currency Derivatives in India Evidence from Future Market with special reference to BSE Ltd, Mumbai. International Journal of scientific research and management (IJSRM).

[18] Vashishtha, A., \& Kumar, S. (2010). Development of Financial Derivatives Market in India- A Case Study. International Research Journal of Finance and Economics.

[19] Zhang, R. (2012). The Use of Foreign Currency Derivatives and Firm Value In U.S. Faculty of Economics and Business Administration.

*Corresponding author.

E-mail address: dishaguptapimr1113@gmail.com 